\title{
RANCANG BANGUN DAN UJICOBA MESIN PEMISAH DAGING IKAN BERDAYA LISTRIK RENDAH
}

\section{Design and Trial Test of a Low Power Fish Bone Separator}

\author{
Bakti Berlyanto Sedayu1* I Made Susi Erawan', dan Bagus Sediadi Bandol Utomo² \\ ${ }^{1}$ Loka Penelitian dan Pengembangan Mekanisasi Pengolahan Hasil Perikanan, KKP. \\ Jl. Imogiri Barat KM 11.5 Jetis, Bantul, DI Yogyakarta 55781 \\ ${ }^{2}$ Balai Besar Penelitian dan Pengembangan Pengolahan Produk dan Bioteknologi Kelautan dan Perikanan, KKP \\ JI. K.S. Tubun Petamburan VI, Jakarta Pusat 10260 \\ * Korespondensi Penulis: bakti@kkp.go.id
}

Diterima 25 Februari 2013, Disetujui 13 November 2013

\begin{abstract}
ABSTRAK
Rancang bangun mesin pemisah daging ikan (fish bone separator) berdaya listrik rendah telah dikembangkan untuk mendapatkan mesin yang aplikatif untuk pengolahan ikan skala kecilmenengah. Mesin didesain lebih sederhana serta dibuat dengan ukuran yang lebih kecil dari produk komersial sejenis dan digerakkan dengan motor bertenaga maksimum $1 \mathrm{HP}$. Mesin dirancang berdasarkan mekanisme kerja silinder berpori yang berputar. Sabuk penekan yang menghimpit ikan pada permukaan silinder mengelilingi sekitar setengah perimeter silinder berpori, sedangkan setengah permukaan lainnya berfungsi untuk pemasukan bahan (ikan) dan scrapping permukaan silinder. Kecepatan antara sabuk penekan dan permukaan silinder sedikit berbeda untuk menghasilkan gesekan pada proses pemisahan. Profil mesin, prinsip kerja, serta perbandingan performansinya dengan mesin komersial sejenis dipaparkan secara deskriptif dalam tulisan ini. Hasil uji performansi mesin pemisah daging ikan dengan menggunakan ikan kuniran (Upenephelus sulphureus) menunjukkan bahwa kapasitas dan kecepatan kerja mesin yang lebih rendah dibandingkan mesin komersial, mampu menghasilkan rendemen dan mutu daging lumat yang lebih baik.
\end{abstract}

KATA KUNCI: mesin pemisah daging ikan, rancang bangun, ujicoba, pengolah ikan skala kecil-menengah

\begin{abstract}
Design of a low power fish bone separator has been developed to obtain an appropriate machine intended for small-medium scale fish processing. The fish bone separator was constructed more simple in design and smaller in size compared to the commercial ones, and only powered by a 1-HP motor machine. The machine designed was based on a perforated rotating cylinder. A pressure belt that presses the fish against the exterior of the drum surface surrounds about half of the drum's perimeter, leaving the other half free for fish intake, and drum surface scrapping. The belt is powered at a slight different speed from that of the drum surface, providing the necessary shear action. A description of the developed machine, its working principle, and a comparison with existing commercial machine is presented in this paper. The performance test of the machine using kuniran fish (Upenephelus sulphureus) demonstrated that the machine has lower performance in capacity and production rate than the commercial one. Nevertheless, the minced fish produced by the machine has higher yield and better quality.
\end{abstract}

\section{KEYWORDS: fish bone separator, design, testing, small-medium scale fish processor}

\section{PENDAHULUAN}

Permasalahan meningkatnya biaya peralatan dan mesin pada industri perikanan, serta ketersediaan bahan-baku ikan berkualitas tinggi yang tidak kontinyu menyebabkan naiknya ongkos produksi dan juga keguncangan terhadap pemasaran ikan dan produk perikanan, hal ini kemudian berdampak pada pemanfaatan ikan-ikan non-ekonomis penting (underutilised) dan hasil tangkap samping ke tingkat komersial. Salah satu cara yang paling memungkinkan untuk memanfaatkan jenis ikan-ikan tersebut yaitu melalui pengambilan dagingnya dan meningkatkan nilai tambahnya menjadi produk-produk berbasis daging lumat dan surimi seperti nugget, baso, sosis dan lainnya (Venugopal \& Shahidi, 1998).

Beberapa kendala dalam proses pengolahan ikan, terutama untuk jenis ikan kecil (rucah), adalah 
kesulitan proses pemisahan daging ikan dari tulang dan kulitnya. Sedangkan pemisahan daging ikan tersebut secara manual menggunakan tangan akan membutuhkan banyak waktu dan tenaga kerja sehingga dapat menyebabkan penurunan mutu daging ikan serta meningkatkan ongkos produksi. Pengolahan secara manual dengan tangan masih banyak dilakukan dan masih layak secara ekonomi, namun demikian, pada saat harga produk olahan ikan harus bersaing dengan produk makanan sumber protein lainnya di pasaran, atau nilai produk perikanan yang relatif rendah, maka proses menggunakan mesin menjadi suatu keharusan (Mendelsohn \& Callan, 1980). Umumnya produk pengolahan berbasis daging lumat ikan seperti baso, nugget, dan otak-otak memiliki nilai tambah yang lebih tinggi dibandingkan dengan jenis produk olahan lainnya. Oleh karena itu, mesin pemisah daging dan tulang (fish bone separator) menjadi kebutuhan utama pada proses pengolahannya.

Pengembangan proses pemisahan daging dengan teknologi modern menggunakan meat separatortelah dilakukan sejak akhir 1940 sampai dengan awal 1950. Walaupun mesin pemisah daging dan tulang mekanis telah berkembang sangat pesat sejak awal dikenalkan, namun prinsip kerja dari mesin-mesin terdahulu masih menjadi dasar bagi mesin-mesin saat ini (Newman, 1981). Mesin pemisah daging ikan (fish bone separator) secara umum telah diproduksi dan beredar di pasaran, namun umumnya mesin-mesin tersebut adalah produk impor buatan Jepang, Korea, dan Taiwan sehingga harganya relatif mahal bagi pengolah perikanan skala rumah tangga dan usaha mikro kecil dan menengah (UMKM). Sedangkan hasil uji coba operasional fish bone separator lokal yang produksi oleh Balai Besar Pengembangan dan Pengendalian Hasil Perikanan masih menunjukkan hasil yang kurang optimal, yaitu alat tidak mampu mengepres ikan secara maksimal, dan hanya mampu mendapatkan daging ikan $5 \%$ dari berat awal. Sementara itu alat pemisah daging impor mampu menghasilkan daging ikan 30\% dari berat awal (Burhanuddin et al., 2010)

Penelitian yang berkaitan dengan rancang bangun mesin tersebut juga telah dilakukan (Burhanuddin et al., 2010; Purbayanto et al., 2009). Namun demikian, mesin pemisah daging yang banyak ditemukan di pasaran memiliki kapasitas yang besar atau memerlukan energi listrik yang tinggi. Jenis mesin pemisah daging ikan untuk skala industri yang ada di pasaran yaitu Bibun NDX106 membutuhkan daya 3700 w. Sedangkan pengembangan mesin pemisah daging yang lebih kecil (semi-portable) juga telah dikembangkan oleh Purbayanto (2009) untuk aplikasi di kapal penangkapan ikan, yaitu Suritech, membutuhkan daya $1500 \mathrm{~W}$. Tingginya daya listrik yang dibutuhkan menyebabkan sulitnya mesin pemisah daging untuk diaplikasikan pada industri kecil-menengah. Oleh karena itu, rancang bangun dan rekayasa mesin pemisah daging ikan berdaya listrik rendah dengan prinsip kerja yang sederhana, serta memiliki harga yang terjangkau sangat diperlukan. Tujuan rancang bangun mesin pemisah daging ikan berdaya listrik rendah adalah untuk menyediakan mesin pemisah daging ikan yang dapat digunakan oleh pengolah hasil perikanan skala kecil-menengah secara efisien, yaitu usaha dengan kapasitas sekitar 10-30 kg/produksi.

\section{BAHAN DAN METODE}

Desain mesin pemisah daging ikan dirancang untuk proses produksi bahan pangan, sehingga material mesin yang bersentuhan langsung dengan bahan (ikan) dibuat dari bahan-bahan yang aman dari korosi atau kontaminasi. Ukuran mesin baik dimensi maupun bobot, dirancang lebih kecil atau lebih ringan dari ukuran mesin komersial yang ada di pasaran dengan sumber tenaga listrik yang rendah. Hal ini disesuaikan dengan kondisi unit pengolahan skala kecil-menengah yang umumnya hanya memiliki daya listrik terbatas (450-900 W) dengan kapasitas produksi sekitar $10-30 \mathrm{~kg} / \mathrm{hari}$. Selain itu, sistem kerja mesin dibuat sesederhana mungkin agar mudah dioperasikan oleh operator di unit pengolahan yang umumnya merupakan tenaga kerja dengan keahlian terbatas.

Penelitian ini mencakup tahap perancangan/ desain, perakitan mesin, pengujian mesin, serta analisis produk daging lumat ikan yang dihasilkan. Bahan rancang bangun mesin fish bone separator meliputi: frame siku 50-MS dan UNP 50-MS, roller nylon, rubber silicon, roller bearing, pillow block, gear reducer, motor listrik $1 \mathrm{HP}, \mathrm{V}$ belt, sprocket motor, sprocket reducer, baut, roda, plat stainless steel, dan bahan lainnya. Bahan yang digunakan untuk uji coba mesin yaitu ikan kuniran (Upeneus shulpureus) yang diperoleh dari TPI Eretan Kulon, Indramayu, yang telah dihilangkan kepala, isi perut serta sisiknya. Pengumpanan ikan ke dalam mesin (intake hopper) dilakukan dengan cara memasukkan bagian ekor terlebih dahulu.

Peralatan yang digunakan pada proses rancang bangun antara lain: peralatan las argon dan las listrik, mesin bubut, unit besi pemahat, mesin bor, alat penekuk plat, amplas, peralatan pengecatan, gerinda listrik, meteran, perkakas bengkel dan peralatan lainnya. Alat pengujian yang digunakan antara lain: meteran, stop watch, dan timbangan. 


\section{Desain Fungsional}

Rangka merupakan dudukan dari motor listrik, silinder pemisah, sistem transmisi, serta komponen pendukung lainnya, sehingga harus kuat menahan beban dan getaran selama mesin beroperasi. Silinder pemisah dan sabuk penekan berfungsi untuk mengepres ikan. Ikan yang dipres di antara silinder pemisah dan sabuk penekan akan terpisah antara tulang dan kulit yang menempel pada sabuk pengepres dengan dagingnya yang masuk ke poripori pada silinder, dan secara operasional kekuatan tekan dapat diatur (adjustable) sesuai dengan kapasitas pengepresan yang diinginkan antara sabuk pengepres dan silinder pori-pori. Motor listrik berfungsi sebagai sumber tenaga bagi sistem penggerak transmisi untuk proses pengepresan dan pemisahan daging ikan, sedangkan scrapper berfungsi untuk menahan sisa tulang dan kulit ikan agar ke luar ke tempat pengeluaran dan tidak kembali ke intake hopper (tempat pemasukan ikan). Untuk mengatur kecepatan putaran mesin guna mendapatkan kecepatan pemisahan daging yang optimal, maka mesin dilengkapi dengan inverter.

\section{Perancangan Struktural}

Rangka mesin fish bone separator terbuat dari frame siku MS-50 dan UNP-MS dengan tutup/cover rangka menggunakan plat stainless steel dengan ketebalan $2 \mathrm{~mm}$. Silinder pemisah terbuat dari stainless steel ketebalan $3 \mathrm{~mm}$ dengan diameter 160 $\mathrm{mm}$, panjang $300 \mathrm{~mm}$ dan ukuran lubang pori sebesar $3,5 \mathrm{~mm}$. Motor penggerak yang digunakan yaitu motor listrik-1 phase dengan daya $1 \mathrm{HP}, 220$ volt, sedangkan sistem transmisi yang digunakan antara lain: sabuk (V-beltA-53), rantai (C-40), sprocket dan pulley. Untuk menurunkan kecepatan putar dari motor listrik terhadap silinder pemisah, digunakan gear reducer dengan rasio putaran 30:1. Kemudian, bahan yang digunakan sebagai sabuk penekan (pressure belt) adalah rubber silicone dengan ketebalan $120 \mathrm{~mm}$, lebar $200 \mathrm{~mm}$ dan panjang/keliling $1500 \mathrm{~mm}$, sedangkan scrapper terbuat dari bahan stainless steel.

\section{Uji Performansi Mesin}

Uji performansi mesin dilakukan dengan menggunakan analisis deskriptif numerik yang meliputi uji efisiensi proses pemisahan oleh alat dengan membandingkan kapasitas proses pemisahan teoritis (KPT) dan kapasitas proses pemisahan efektif (KPE) daging dan tulang ikan, dengan perhitungan sebagai berikut:

Kapasitas Proses Pemisahan Teoritis (KPT):

$\mathrm{KPT}=\frac{\mathrm{LVi}}{\text { Pili }}$ Si $(\mathrm{g} / \mathrm{s})$
Kapasitas Proses Pemisahan Efektif (KPE):

$\mathrm{KPE}=\frac{\mathrm{s}}{\mathrm{t}} \quad(\mathrm{g} / \mathrm{s})$

Efisiensi proses pemisahan (Ef) :

$\mathrm{EF}=\frac{\mathrm{KPE}}{\mathrm{KPT}} \times 100 \%(\%)$

Di mana:

$\mathrm{L}=$ lebar efektif drum atau sabuk pemisah $(\mathrm{mm})$

$\mathrm{Vi}=$ Kecepatan linier pengumpanan ikan $(\mathrm{mm} / \mathrm{s})$;

$\mathrm{Vi}=\frac{\mathrm{V} \text { drum }+ \text { belt }}{2}(\mathrm{~mm} / \mathrm{s})$

$\mathrm{Pi}=$ panjang rata-rata ikan yang diumpankan $(\mathrm{mm})$

li = lebar rata-rata ikan yang diumpankan $(\mathrm{mm})$

$\mathrm{Si}=$ rendemen daging lumat atau berat daging per ikan $(\mathrm{g})$

$S=$ berat daging lumat yang dihasilkan dalam satu periode pemisahan $(\mathrm{g})$

$\mathrm{t}$ = waktu satu periode kegiatan pemisahan (s)

Selain efisiensi proses pemisahan, kecepatan produksi juga dievaluasi dengan melakukan penghitungan waktu proses pemisahan oleh mesin/ alat dalam satu siklus produksi.

\section{Rendemen}

Rendemen hasil proses dihitung sebagai presentase berat daging lumat yang dihasilkan oleh alat pemisah daging terhadap berat bahan baku ikan awal.

\section{Analisis kimia}

Daging lumat yang dihasilkan dianalisis kadar proksimat yang meliputi kadar air, kadar abu, kadar protein, dan kadar lemak (AOAC, 2000).

\section{HASIL DAN BAHASAN}

\section{Desain dan Konstruksi Mesin}

Secara umum fish bone separator terdiri atas bagian pemisah daging, motor penggerak dan sistem transmisi. Bagian pemisah (separator) yang berfungsi untuk memisahkan daging ikan dan tulang serta kulit berbentuk silinder berpori sepanjang $300 \mathrm{~mm}$ yang dipasang horizontal menyamping. Silinder pemisah ini terbuat dari plat stainless steel dengan ketebalan $3 \mathrm{~mm}$ berdiameter $160 \mathrm{~mm}$ dan memiliki lubang-lubang perforasi berdiameter $3,5 \mathrm{~mm}$ dengan jarak antar lubang $3 \mathrm{~mm}$; lubang-lubang pada silinder berfungsi sebagai tempat masuknya daging yang sudah dipisahkan dari tulang. Pada bagian bawah silinder terdapat sabuk penekan berukuran panjang $1600 \mathrm{~mm}$, 
tebal $12 \mathrm{~mm}$, dan lebar $200 \mathrm{~mm}$ yang terbuat dari rubber silicone dan berfungsi sebagai penekan ikan yang akan dipisahkan dagingnya dan pembawa tulang dan kulit ikan ke bagian pengeluaran tulang. Pada bagian atas permukaan silinder dipasang scrapper yang terbuat dari stainless steel yang berfungsi menahan tulang dan kulit ikan yang melekat pada permukaan silinder agar jatuh ke sabuk penekan untuk dibawa ke bagian pengeluaran tulang. Gambar mesin fish bone separator seperti terlihat pada Gambar 1.

Motor penggerak yang digunakan yaitu unit motor listrik 1-Phase, berdaya maksimal 1-HP dengan kecepatan putaran $1400 \mathrm{rpm}$, motor ini menggerakkan silinder pemisah dan sabuk penekan. Sistem penerusan daya dari fish bone separator adalah menggunakan sprocket dan rantai dari poros motor listrik ke poros gear reducer dengan rasio putaran 30:1. Gear reducer menggunakan pully 1 alur dengan $V$-belt jenis A-53 ke poros silinder pemisah, sedangkan dari poros silinder pemisah menggunakan roda gigi untuk menggerakkan sabuk penekan. Untuk mendapatkan kecepatan optimal saat proses pemisahan daging ikan, maka kecepatan putaran motor penggerak dapat diatur melalui inverter. Spesifikasi fish bone separator yang telah dirancang disajikan pada Tabel 1.

Dibandingkan dengan mesin pemisah daging komersial, yaitu mesin Bibun NDX106 Meat Separator dan Suritech, maka mesin yang dirancang ini memiliki dimensi, bobot, dan juga daya listrik yang lebih rendah (Tabel 2).

\section{Mekanisme Pemisahan Daging Ikan}

Alat pemisah daging ikan dibuat berdasarkan prinsip pemisahan daging ikan dengan tulang dan kulitnya yaitu dengan memaksa daging ikan masuk melalui pori-pori pada permukaan silinder (perforated drum) dengan mengkombinasikan gaya tekan dan

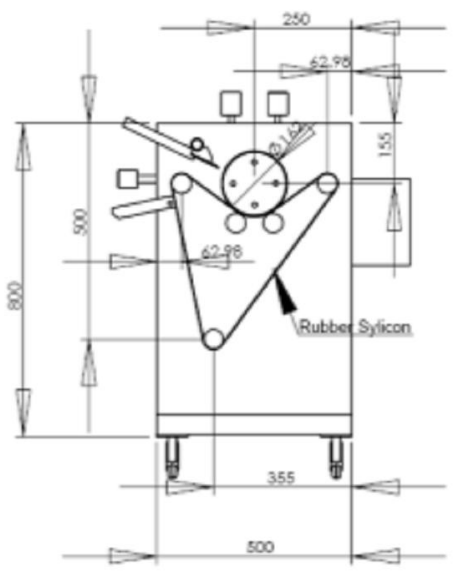

Tampak depan/Plan

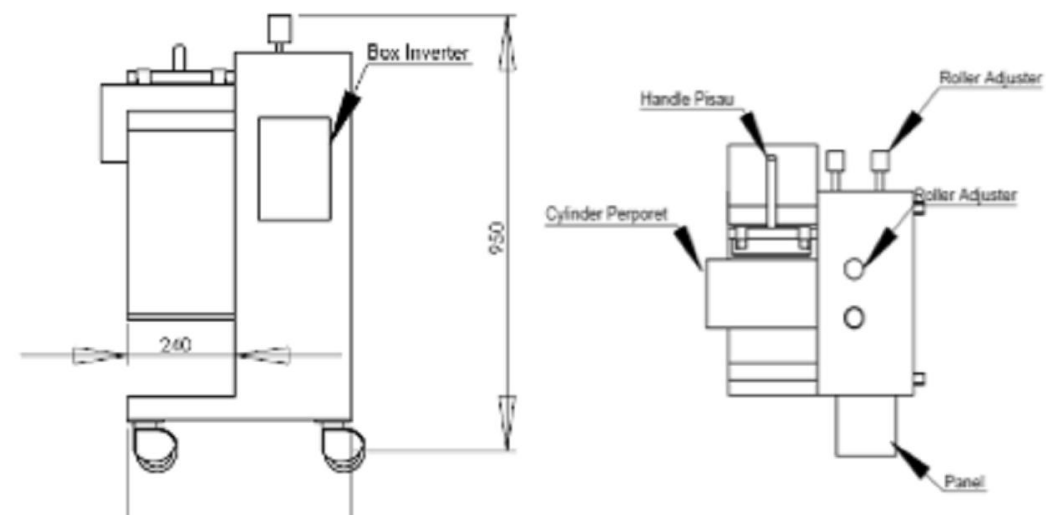

Tampak atas/Elevation

Tampak samping/Side view

Dimensi dalam $\mathrm{mm} /$ dimensions are in $\mathrm{mm}$

Tidak berskala/not to scale

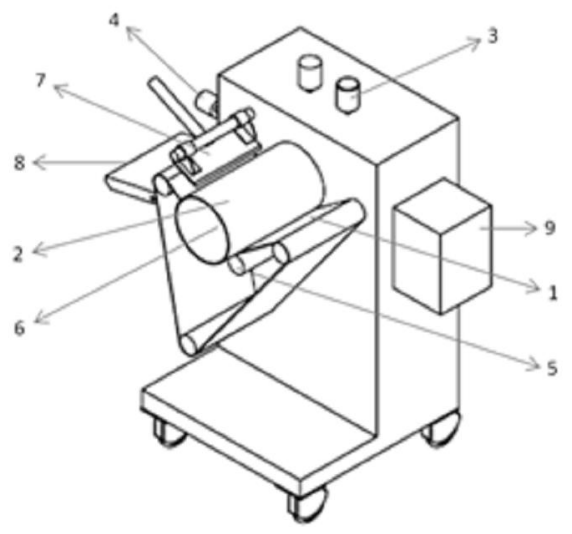

Keterangan/Note:

1. Pemasukkan ikan/Intake happer

2. Silinder pemisah/Separator drum

3 \& 4. Pengatur tekanan sabuk/Preassure belt adjuster

5. Roller penekan/Pressure roller

6. Pengeluaran daging ikan/Deboned flesh exit hopper

7. Scrapper

8. Pengeluaran limbah/Waste exit hopper

9. Inverter

Gambar 1. Desain mesin pemisah daging ikan.

Figure 1. Design of fish bone separator. 
Tabel 1. Spesifikasi mesin pemisah daging ikan

Table 1. Fish bone separator specification

\begin{tabular}{lc}
\hline \multicolumn{1}{c}{ Parameter/Parameters } & Spesifikasi/Specification \\
\hline Dimensi/Dimension & 500 \\
Panjang/Length $(\mathrm{mm})$ & 500 \\
Lebar/Width $(\mathrm{mm})$ & 800 \\
Tinggi/Height $(\mathrm{mm})$ & $1-\mathrm{HP} \times 220$ \\
\hline Penggerak/Engines & $30: 01: 00$ \\
Motor & Delta VFD-DEL 220V \\
Reducer & Inverter
\end{tabular}

Tabel 2. Spesifikasi mesin pemisah daging ikan dibandingkan mesin komersial

Table 2. Spesifications of fish-bone separators compared to commercial separator

\begin{tabular}{lccc}
\hline \multicolumn{1}{c}{$\begin{array}{c}\text { Parameter/ } \\
\text { Parameters }\end{array}$} & $\begin{array}{c}\text { Bibun NDX106 } \\
\text { Meat Separator }\end{array}$ & Suritech ${ }^{2}$ & $\begin{array}{c}\text { Mesin Pemisah Daging Ikan Hasil } \\
\text { Rancangan/Experimental Fish- } \\
\text { Bone Separator }\end{array}$ \\
\hline Dimensi/Dimension (mm) & 1525 & 900 & 500 \\
Panjang/Length (mm) & 980 & 780 & 500 \\
Lebar/Width (mm) & 1192 & 750 & 800 \\
Tinggi/Height (mm) & 800 & 210 & 80 \\
\hline Bobot/Weight $(\mathrm{kg})$ & 3700 & 1500 & 750 \\
\hline Daya listrik/Electric power (watt) & &
\end{tabular}

Sumber/Sources: 1 Purbayanto et al. (2009) dan 2 Bibun Meat Separator-Manual Guide

gaya geser sehingga posisi ikan terhimpit di antara permukaan silinder yang berlubang/berpori dan sabuk penekan. Hal ini memberikan kesempatan untuk ekstrusi daging melalui lubang-lubang tersebut, sehingga tidak hanya tulang, tetapi kulit juga tetap berada di bagian luar silinder (Booman et al., 2010).

Setelah motor penggerak mesin fish bone separator dinyalakan dan silinder pemisah berputar, maka ikan yang telah disiangi diumpankan pada intake hopper dan masuk ke bagian pemisah. Sabuk penekan akan menekan ikan bersama dengan silinder pemisah, dan memisahkan daging dari kulit dan tulang ikan. Daging ikan akan masuk ke silinder pemisah melalui lubang perforasi, sedangkan tulang dan kulit ikan akan dibawa oleh sabuk penggiling ke bagian pengeluaran tulang (Gambar 2).

\section{Uji Coba Mesin Fish Bone Separator}

Berdasarkan hasil uji coba mesin pemisah daging ikan yang dilakukan terhadap jenis ikan kuniran, kapasitas proses pemisahan daging dan tulang ikan yaitu $1,33 \mathrm{~g} / \mathrm{s}$ dengan nilai efisiensi pemisahan daging $4,8 \%$. Jika dibandingkan dengan mesin Suritech yang dirancang oleh Purbayanto et al. (2009) mesin pemisah daging ikan yang dirancang masih menunjukkan kapasitas dan efisiensi yang lebih rendah. Untuk pengolahan ikan jenis biji nangka, yang memiliki bentuk dan ukuran yang serupa dengan kuniran, mesin Suritech memiliki kapasitas dan nilai efisiensi proses pemisahan sebesar 19,58 $\mathrm{g} / \mathrm{s}$ dan $4,4 \%$. Ujicoba pemisahan ikan kuniran dengan mesin komersial skala industri buatan Jepang Bibun NDX106 Meat Separator memberikan kapasitas produksi yang jauh lebih tinggi yaitu $26,6 \mathrm{~g} / \mathrm{s}$.

Hal tersebut disebabkan pada saat pengumpanan melalui intake hopper, jumlah ikan yang dimasukkan hanya sedikit dan tidak memenuhi bidang pengepresan yang memiliki lebar $25 \mathrm{~cm}$ sehingga masih terdapat ruang kosong. Bahan sabuk penekan yang terbuat dari rubber silicone menyebabkan 

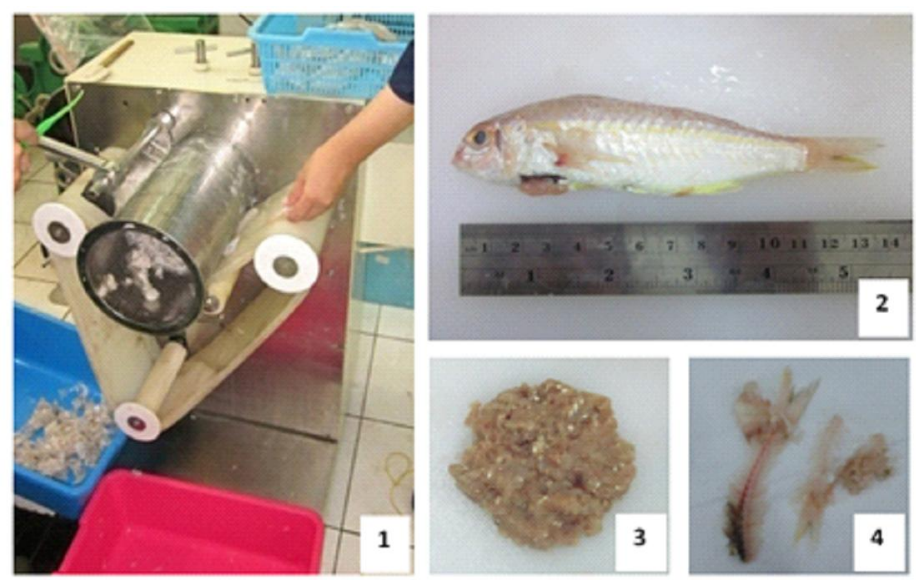

Gambar 2. 1) Proses pemisahan daging ikan; 2) Ikan kuniran; 3) Daging lumat; 4) Limbah tulang dan kulit. Figure 2. 1) Fish Deboning Process; 2) Upeneus sulphureus; 3) Minced fish; 4) Fish waste (bones and skins).

licinnya permukaan sabuk sehingga sering menyebabkan selip dan lebih sulitnya ikan dimasukkan kedalam intake hopper, sehingga dibutuhkan bantuan secara manual dengan cara mendorong ikan dengan paksa, dan hal ini juga menurunkan kapasitas produksi mesin. Diameter silinder pemisahan yang lebih kecil jika dibandingkan dengan mesin komersial juga menyebabkan lebih sulitnya ikan masuk ke dalam intake hopper, hal ini disebabkan oleh lebih kecilnya sudut bukaan untuk pemasukan ikan antara silinder pemisahan dan sabuk pengepres sehingga memperlambat waktu proses pemisahan daging. Oleh karena itu, untuk meningkatkan kapasitas produksi dan efisiensi mesin pemisah daging ikan ini dibutuhkan silinder pemisahan yang lebih panjang (pengumpanan lebih lebar) dengan tetap mempertahankan kecepatan putar silindernya, sedangkan untuk memperlancar pengumpanan, diperlukan mekanisme tambahan pada bagian intake hopper seperti jari-jari penekan, dan diameter silinder harus dibuat lebih besar lagi.

Namun demikian, rendemen daging lumat ikan kuniran yang dihasilkan oleh mesin yang telah dirancang menunjukkan hasil dua kali lebih besar, yaitu 71,8\%, dibandingkan mesin Bibun NDX106 Meat Separator yang menghasilkan rendemen $37,8 \%$. Hal ini dipengaruhi oleh kekuatan pengepresan dan juga kecepatan putaran motor penggerak yang diatur lebih lambat dibandingkan mesin komersial, sehingga kontak antara ikan dengan silinder pemisahan menjadi lebih lama dan proses ekstrusi daging menjadi lebih efektif.

Dari hasil analisis kandungan kimia daging lumat yang dihasilkan (Tabel 3), parameter yang dapat dibandingkan untuk mengetahui mutu produk antara lain kadar abu, yang dapat merepresentasikan jumlah tulang yang masih terbawa dalam daging lumat selama proses pemisahan. Kadar abu yang dihasilkan dengan menggunakan mesin fish bone separator hasil rancangan menunjukkan jumlah yang lebih kecil, yaitu $4,45 \%$ (DB), dibandingkan pada daging lumat hasil pemisahan menggunakan mesin Bibun NDX106 Meat Separator yaitu 5,00\% (DB).

Adapun jumlah kandungan abu dalam daging lumat hasil pemisahan dengan mesin pemisah daging hasil rancangan yaitu sebesar $0,17 \%$. Hasil ini

Tabel 3. Komposisi kimia daging lumat

Table 3. Chemical composition of the minced fish

\begin{tabular}{ll}
\hline \multicolumn{1}{c}{$\begin{array}{c}\text { Komposisi Kimia/ } \\
\text { Chemical Composition }\end{array}$} & Nilai/Value (\%) \\
\hline Kadar air/Moisture content & 83.96 \\
Kadar abu/Ash content (DB) & 4.45 \\
Kadar lemak/Lipid content (DB) & 6.85 \\
Kadar protein/Protein content (DB) & 76.98 \\
\hline DB = Dry Base
\end{tabular}


menunjukkan bahwa jumlah tulang yang terbawa dalam daging berada pada level rendah, dan daging hasil pemisahan dalam kisaran yang dapat diterima. Kandungan kalsium kurang dari 0,5\% termasuk dalam katagori rendah untuk daging lumat hasil pemisahan secara mekanik (USDA, 1975). Menurut Lovell \& Apolinario (1976), prosedur assay kandungan kalsium (Ca) lebih mudah jika dibandingkan dengan metode penghitungan total tulang/duri ikan dan seharusnya metode ini dipilih untuk digunakan dalam metode penghitungan tulang/duri ikan yang terbawa dalam daging lumat hasil pemisahan.

\section{KESIMPULAN}

Percobaan rancang bangun mesin pemisah daging ikan (fish bone separator) menghasilkan mesin yang memiliki daya listrik lebih rendah dibandingkan mesin komersial sejenis. Hasil ujicoba mesin fish bone separator menunjukkan nilai efisiensi dan efektifitas kerja mesin yang masih rendah sehingga perlu disempurnakan untuk meningkatkan performansinya. Namun demikian, produk daging lumat hasil pemisahan menunjukkan rendemen yang lebih tinggi dan kualitas yang lebih baik dibandingkan dengan daging lumat yang dihasilkan dari mesin komersial.

\section{DAFTAR PUSTAKA}

AOAC. 2000. Official Methods of Analysis of AOAC International, 17th ed. AOAC International, Md., USA
Booman, A., Márquez, A., Parin, M.A., and Zugarramurdi, A. 2010. Design and testing of a fish bone separator machine. Journal of Food Engineering. 100: 474479.

Burhanuddin, Hoetagaol, T.M., dan Prodiana, N. 2010. Rancang bangun alat pemisah daging dan tulang (Meat Bone Separator) dalam rangka pengembangan produk bernilai tambah. Laporan Akhir Balai Besar Pengembangan dan Pengendalian Hasil Perikanan 2010. Jakarta. 21 p.

Lovell, R.T. and Apolinario, K. 1976. Yield and quality of mechanically separated flesh from several species of cultured freshwater fish. Proceeding of The First Annual Tropical and Subtropical Fisheries Technological Conference. 1: 565-584.

Mendelsohn, J.M. and Callan, J.G. 1980. Evaluation of a prototype fish cleaning machine with proposals for a commercial processing line. Marine Fisheries Review. p. 38-43.

Newman, P.B. 1981. The separation of meat from bone - A reviews of the mechanics and the problems. Meat Science. 5: 171-200.

Purbayanto, A., Santoso, J., Riyanto, R., Purnomo, A., Pramono, B. dan Susanto, A. 2009. Prosiding Seminar Nasional Teori dan Aplikasi Teknologi Kelautan. A-177 - A-185 p.

United State Department of Agriculture (USDA). 1975. Preparation of mechanically deboned meat and meat fatty tissue. Meat and Poultry Inspection Bulletin 865, Animal and Plant Health Inspection Service, U.S.D.A. Washington, D.C.

Venugopal, V. and Shahidi, F. 1998 Traditional methods to process underutilized fish species for human consumption. Food Rev. Int. 14(1): 35-97. 